\title{
アルマイト皮膜の触媒体としての機能化とその可能性
}

亀山秀 雄 ${ }^{\mathrm{a}}$

\author{
a 東京農工大学 工学府 ( ⿳ 184-8588 東京都小金井市中町 2-24-16)
}

\section{Functionalization and its Possibility as a Catalyst Object of Anodic Oxide Film}

\section{Hideo KAMEYAMA ${ }^{\text {a }}$}

${ }^{a}$ Faculty of Engineering, Tokyo University of Agriculture and Technology (2-24-16, Nakachyo, Koganei-shi, Tokyo 184-8588)

Keywords : Catalyst, Anodic Oxidation Film, Chemical Reactor

\section{1.はじめに}

アルマイト触媒は，アルミニウムの材料特性である連続性, 加工性, 伝熱性, 軽量性に加えて反応性を有する新しい触媒 材料である。様々な形状(線状，板状，管状，箔状，貫通箔状， 波状，セレート状，スポンジ状，マイクロ細管状等）の触媒 を製造することができる。母材にアルミクラッド材を用いる

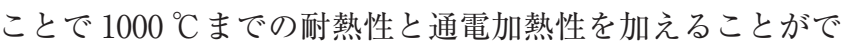
きる。さらに，放電プラズマ電極にも使用できるので，プラ ズマ化学反応にも利用できる。触媒と放電を組み合わせれば 放電触媒反応器として利用できる。また，近年注目されてい るマイクロリアクターの反応材料にも使用されている。この ように, 従来の触媒反応器には無い種々の機能を有する触媒 として幅広い可能性を有している。要はこの機能を活用して 新しい触媒反応器をどのようにデザインするかにかかってい る。現在, 応用分野として環境・エネルギー技術分野への応 用が考えられており, 揮発性有機物質(VOC)の触媒燃焼, 自動車排ガス浄化, オゾン発生, 脱臭, 燃料電池用の燃料改 質，アンモニア合成などの触媒として実用化が検討されてい る $^{1,2)}$ 。研究レベルは, 大学での基礎研究, アルマイト関連 研究所での実用化研究, アルマイト触媒を用いた装置製造を 行う企業も存在し, 基礎から事業化まで幅広い柔軟な対応が できる体制にある。

ここでは,アルマイト触媒の製造方法と利用事例を紹介する。

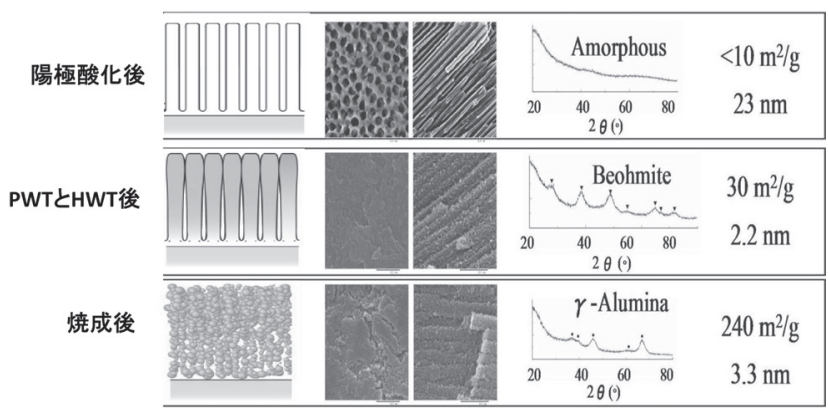

図 1 アルマイト触媒調製の手順

\section{2．アルマイト触媒の製造方法}

陽極酸化基板を熱水に浸漬後，焼成することでアルミナ層 が多孔質化し触媒担体に適した構造になる。この触媒担体層 はアルミニウム金属上に形成されているので通常のアルミナ 粒状触媒に比べて触媒体としての熱伝導度が 20 倍以上ある。 アルマイト触媒の調製手順を図 1 に示す。

(A) 市販純アルミニウムを洗浄した後, 直流電流で陽極酸 化する。酸の種類, 温度や電流密度によって数百 $\AA$ の細孔 を持つアルミナ層が形成される。条件によって平衡厚みが存 在し, 最大で数百 $\mu \mathrm{m}$ のアルミナ層がアルミニウム上に形成 される。陽極酸化を高い電流密度 $\left(100 \sim 1200 \mathrm{~A} / \mathrm{m}^{2}\right)$ で擋拌冷 却しながら行うと短時間でアルマイト被膜が形成できる。 図 2 に膜厚と時間との関係を電流密度をパラメーターとして 示す。高速アルマイト処理は，アルマイト触媒の量産化に不 可欠な技術であるが除熱技術が重要である。

(B) 空隙率の小さいアルミナ皮膜を酸に浸漬することで空 隙率を大きくすることができる。これを細孔径拡大処理 (PWT) と呼ぶ。これにより細孔内部からのアルミナ層溶解 によって細孔径が大きくなり空隙率が増大する。この処理を

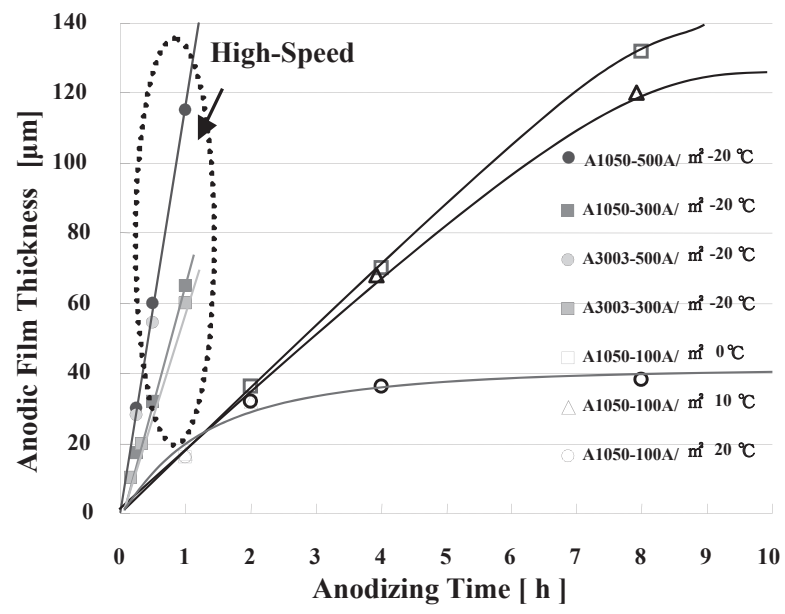

図 2 膜厚と処理時間の関係 
行うと多孔質化処理が酸化皮膜全体に及び， $\mathrm{RF}$ 值を高くす ることができる。ただし浸漬によってアルミナ層厚みも薄く なり白金担持量が減少するので最適な酸浸漬時間を検討する 必要がある。

(C) PWT 処理を行った基板を $80{ }^{\circ} \mathrm{C}$ の熱水に浸漬する (HWT)。陽極酸化で生成した無定形アルミナは水和によっ て擬べーマイトへ変化する。熱水処理時に白金，ニッケルな どの触媒種を混入することでアルミナ層の水和と同時に触媒 金属種がアルミナ層中に担持される。

(D) 熱水処理後, $350{ }^{\circ} \mathrm{C}$ 以上で焼成するとアルミナの水和 水が脱離し $\gamma$ アルミナに変化する。水和水の脱離の際にアル ミナ層は $20 \AA$ を中心とする平均細孔径をもち, $100 \mu \mathrm{m}$ の層 厚みで見掛け面積の 30000 倍以上の表面積を持つ多孔質アル ミナ層へ変化する。この多孔質さをラフネスファクター (Roughness Factor：RF=BET 表面積 $/$ 見掛け面積)として定 義する。また触媒金属を含む溶液を用いて熱水処理した場合 には多孔質アルミナ層中に触媒金属を高分散に担持した触媒 層が形成される。

(E)アルマイト担体に触媒を担持する方法は 2 種類ある。 含浸担持と電解担持である。含浸担持は, 担持する触媒の水 溶液をアルカリ側にアンモニア水で $\mathrm{pH}$ 調製した溶液にある 温度で焼成後の基板を使用して含浸と乾燥と焼成を行う操作 を繰り返して触媒を担持する方法である。また，熱水処理時 に触媒種を混入することでアルミナ層の水和と同時に触媒金 属種がアルミナ層中に担持される。

電解担持は電解着色の原理を使用して, 電気的に多孔質ア ルミナに担持させる方法であり，短時間で均一に担持でき る ${ }^{3)}$ 。図 3 にベンゼンの触媒燃燒を含浸担持触媒 (Cat.3B) と 電解担持触媒 (Cat.E) で性能を比較した結果である。反応特 性に差異はない。表 1 に両触媒の特性を示す。電解担持触媒 の方が，触媒調整時間が $1 / 60$, 担持温度が $20^{\circ} \mathrm{C}$, 白金担持 量が 1/6 であるが反応性に違いはないことがわかる。

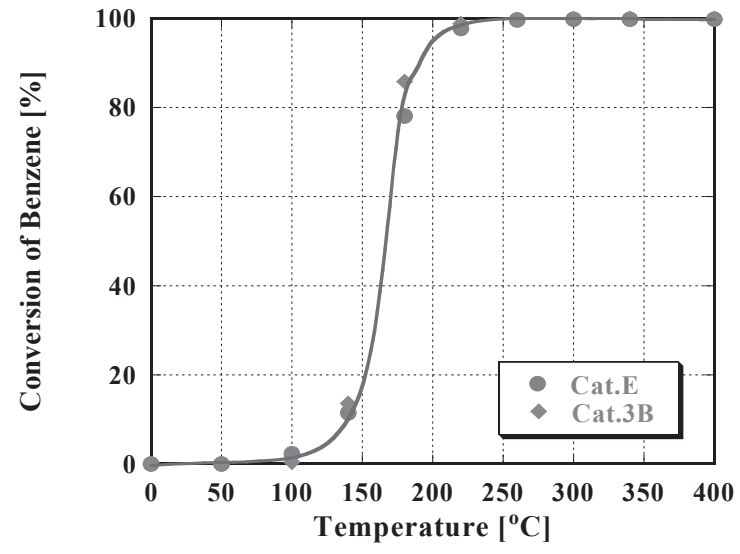

図 3 同じ反応条件下での触媒性能比較

表 1 含浸担持触媒 (Cat.3B) と電解担持触媒 (Cat.E) の特性比較

\begin{tabular}{c|c|c|c|c|c}
\hline & PWT & Method & Pt $\left[\mathrm{g}-\mathrm{Pt} / \mathrm{m}^{2}\right]$ & R.F. & Film $[\mu \mathrm{m}]$ \\
\hline Cat.E & - & $20{ }^{\circ} \mathrm{C}, 2 \mathrm{~min}$ & 0.2 & 2000 & 57 \\
\hline Cat.3B & - & $80{ }^{\circ} \mathrm{C}, 2 \mathrm{~h}(\mathrm{HWT})$ & 1.2 & 7000 & 58 \\
\hline
\end{tabular}

\section{3．通電式耐熱アルマイト触媒}

クラッド材はもともと覆うという意味であり，二つ以上の 金属材料の表面の間に金属的結合を生じさせて一体化させた 積層型の複合材料である。母材に, 強度がある安価な材料を 使い，表面の金属には耐食性，耐摩耗性，伝熱性，導電性な どの機能を持つ材料を圧延，爆着，肉盛などで接合している。

本研究で使用したのは，アルミニウムーニッケル・クロム 鋼クラッド材は，厚さ約 $50 \mu \mathrm{m}$ 電熱抵抗合金のニッケル・ク ロム鋼 $(78 \mathrm{Ni}-20 \mathrm{Cr}-1.2 \mathrm{Si})$ を母材とし，その両面に厚さ 40 $50 \mu \mathrm{m}$ のアルミニウムを圧延により張合わせ基板である。 図 4 に断面を示す。

クラッド材のアルミニウム層を陽極酸化し，アルミナ皮膜 を生成して，それを通常のアルマイト触媒製造と同じPWT と HWT を施し，焼成しでyアルミナ化することで，耐熱ア ルマイト担体になる。この耐熱アルミナ担体に白金, ニッケ ルなどの触媒を担持させたものが耐熱アルマイト触媒である。 さらに，電気抵抗が大きいニッケル・クロムが通電加熱可能 な芯材なので通電使用することにより通電式耐熱アルマイト 触媒となる。ここで拡散層とアルミナ皮膜と触媒としての特 徵を記す ${ }^{4)}$ 。

拡散層：クラッド材を $500{ }^{\circ} \mathrm{C}$ 以上で焼成することによって, アルミニウムとステンレスの成分が相互拡散し拡散層を形成 し接合し，中間的な層が生じる。拡散層はアルミニウム層界 面との密着性があるため, 加熱するときの熱膨張率の違いを ある程度緩和して，アルミニウム層の上のアルミナ層の剥離

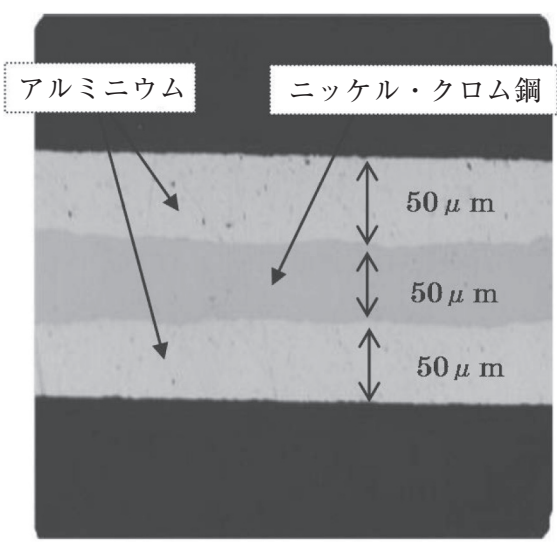

図４アルミクラッド材の断面
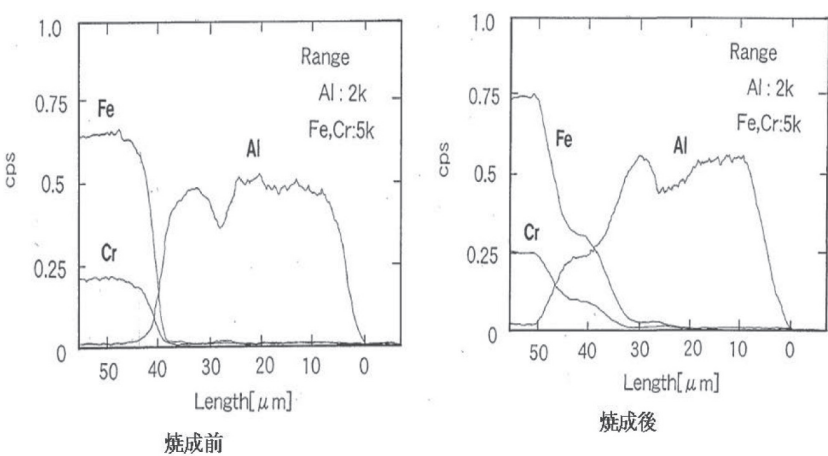

図 5 EPMA で観察された拡散層 
が抑制させる。EPMA で観察された拡散層の存在を図 5 に示す。 $\gamma$ アルミナ皮膜：アルミナ層の $\gamma$ 化処理を行うと無数のひび 割れが入る。このひび割れによって, 表面に平行な方向のア ルミナの結合を切断することで熱応力を吸収し，耐熱試験の ときに，ステンレスとアルミナの熱膨張率の差によって生じ るアルミナの剥離を防ぐことができる。 $\gamma$ 化処理したアルマ イト触媒体の表面状態を図 6 に示す。

この通電加熱アルマイト触媒担体の通電特性を図 7 に示す。 通電することによって素早く温度が上昇し, 数秒で $800{ }^{\circ} \mathrm{C} に$ 達しする。温度変化の速度は $100{ }^{\circ} \mathrm{C} / \mathrm{s}$ 以上である。これを 5000 回繰り返しても皮膜の剥がれは見られなかった。この 結果から, 通電加熱による触媒反応時において優れた熱応答 性をもつことが期待され，スタートアップの早い水蒸気改質 器の開発を実現できる。

触媒の特徵 :

(1)スタートアップが早い, 反応の均一性がよい。

(2)電流を流すにより, 触媒担体を加熱出来るので反応温度 が制御しやすい。

(3)処理ガスを加熱せず，直接に触媒体を加熱するので，反 応が早く起きることができ，省エネルギーが可能。

(4)通常, 反応ガスを加熱するために, 外部のヒーターが使 用されることに対して, 通電式耐熱触媒装置は, 外部ヒー ターが不要なので装置の小型化が可能。

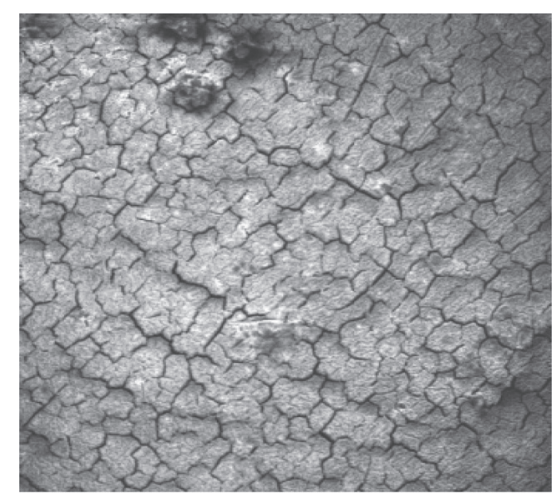

図 6 通電加熱アルマイト触媒の表面

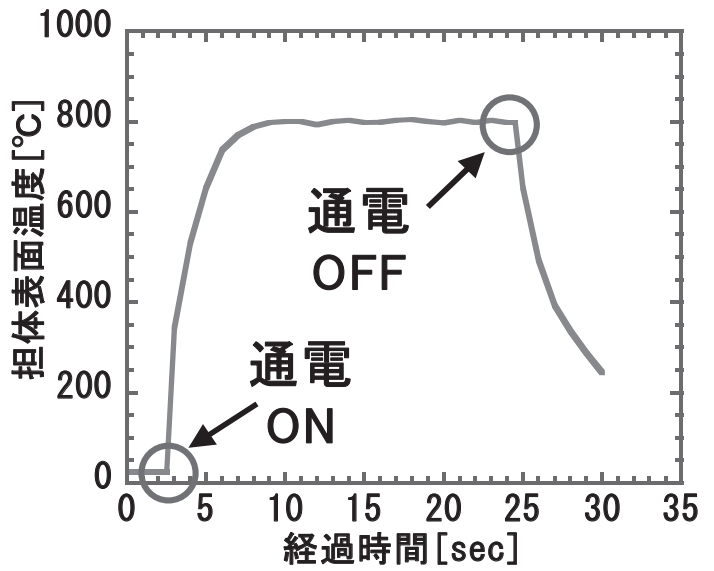

図 7 通電加熱実験結果

\section{4.アルマイト放電電極}

アルマイト触媒と同じ手順で多孔質なアルミナ皮膜を形成 させた平板を電極として使用し，対極に誘電体を配置し， 数 $\mathrm{kHz}$ の周波数で数 $\mathrm{kV}$ の交流電圧を負荷させると, 安定な 無声放電が得られる。この放電電極を用いると空気からオゾ ンやNO を得ることができる。さらに，多孔質な電局面に触 媒を担持させて, 放電触媒として利用すると, 放電だけと触 媒だけの時に比べて両方を同時に行うことで高い反応率を得 ることもできる。図 8 でエタノールの水蒸気改質反応でその 効果を示す。放電と触媒のシナジー効果が見られる。

\section{5．アルマイト触媒の開発事例}

アルマイト触媒は研究開発から 30 年を経過し, 触媒製造 技術としてある程度確立していると言える。これからは, 様々 なアルミニウム素材を製造する業界が触媒製造技術の部分を コアー技術として製造した触媒で様々な利用を自由に考える というアルマイト触媒利用技術プラットフォームが形成され ていくことにより，オープンイノベーションが行われると思 われる。イメージを図 9 に示す。

この中で, 今までの粒状触媒やハニカム触媒とは, 全く異 なる形状の触媒を紹介する。

5. 1 セレート型構造体触媒

セレート構造をしたアルミニウム構造体をそのままアルマ

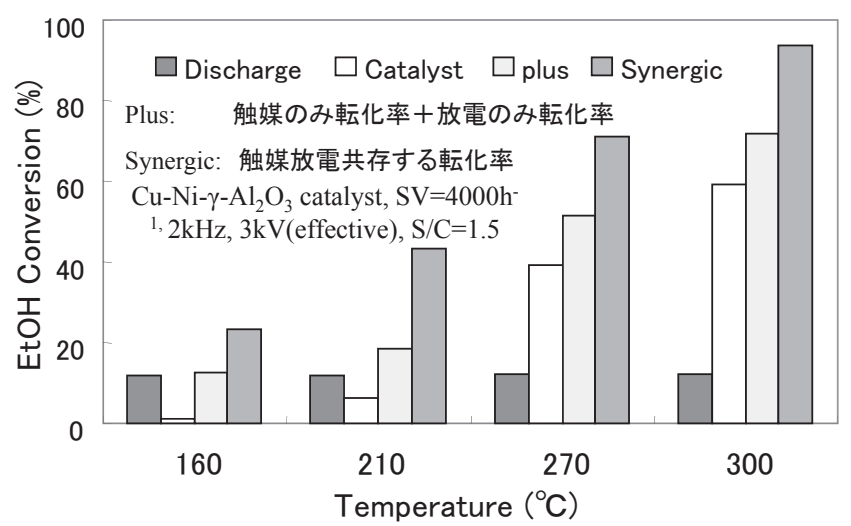

図 8 エタノールの改質反応での放電と触媒のシナジー効果

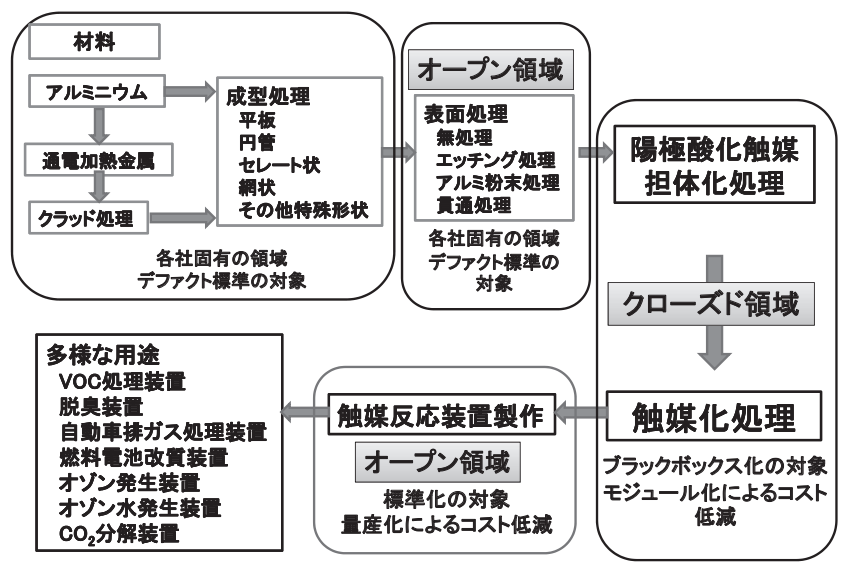

図 9 アルマイト触媒技術のプラットフォーム戦略 
イト触媒化する技術でめっき処理技術を利用して，吊り下げ 式で量産できる。触媒面と反応ガスとの接触を良くし，単位 体積当たりの反応面積を稼ぐには，触媒の形状を工夫するこ とが望まれる。VOCの燃焼では，セレート構造の場合は， 通常の 3 倍の SV90000 $\mathrm{h}^{-1}$ でも反応率が頭打ちにならないた め, 同じ体積で 3 倍の排ガス処理が可能なコンパクト化が図 れる。

\section{2 アルミ箔アルマイト触媒 ${ }^{5), 6}$}

図 10 に示すようにコンデンサー用のエッチング箔やアル ミ箔上にアルミ粉を焼結させた素材をそのままアルマイト触 媒化する。触媒がロールで巻かれた状態で出荷でき, 触媒馢 を利用した様々な反応器が設計できる。

図 11 に板状のアルマイト触媒との比較を示す。低温活性は, 触媒分散性の高いエッチング䇴触媒が優れているが, 高転化 率領域では，表面に凹凸のある粉焼結体触媒の方が反応ガス と触媒との接触が良いため, 高い性能を示している。

\section{3 貫通孔を有するアルミ箔触媒}

貫通孔を有するエッチングアルミ䇴を陽極酸化と触媒化処 理を施すと，貫通孔が反応細管になる。図 12 に示すように， 厚さ $100 \mu \mathrm{m}$, 直径 $11 \mathrm{~mm}$ の円形の䇴を用いると, 直径 1〜 $3 \mu \mathrm{m}$ ，長さ $75 \sim 100 \mu \mathrm{m}$ の反応管を 54 万本束ねた形の反応 器に相当するマイクロリアクターを作ることができる。

パラメーターは, 膜厚, ピット径, ピット密度, 細管内壁 のアルマイト厚さなど従来の触媒設計では考えなかった因子

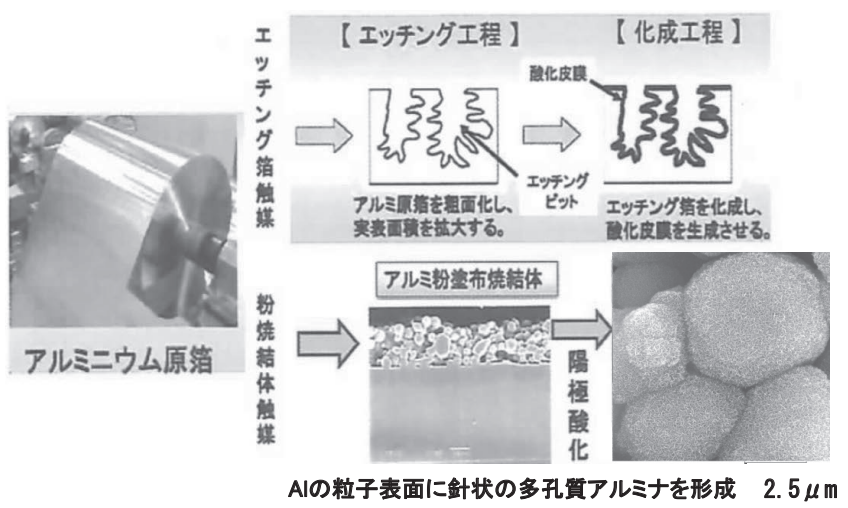

図 102 種類のアルマイト䈃触媒の形状

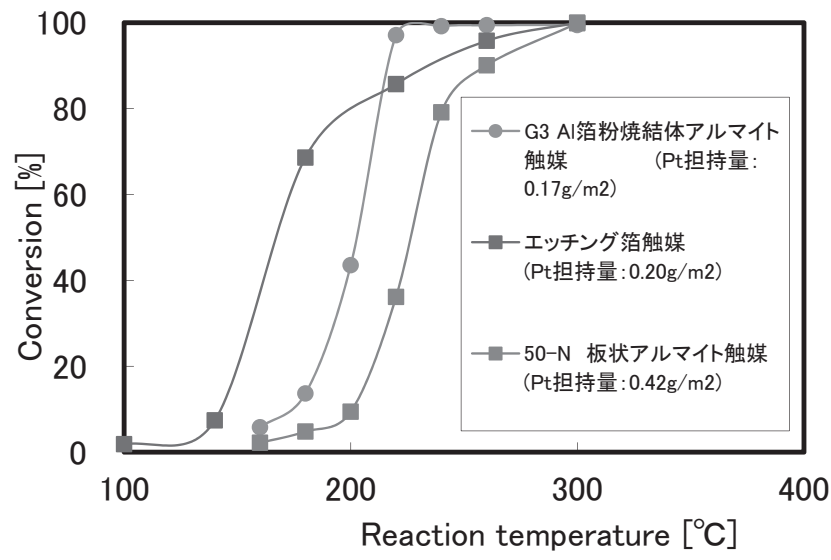

図 11 板状および箔状触媒の活性比較
が， 反応速度に重要な役割を持つことになり，マイクロリア クター触媒の新しい領域を開拓することになる。この種の触 媒反応器の今後の展開が期待される。

\section{6．アルマイト触媒の実用化事例}

現在使用されている 3 種類のアルマイト触媒の利用形態を 図 13 に示す。耐熱 $500{ }^{\circ} \mathrm{C}$ のアルマイト触媒は, VOC 分解装 置として事業化された。アルマイト触媒の量産化技術は, ア ルマイト触媒研究所から 2007 年に浜松のめっき会社に技術 移転され，1Lのセレート型構造体月産 2000 個の製造能力 で生産できるようになった。クラッド材を使用する通電式耐 熱アルマイト触媒は, 脱臭装置で事業化された。現在管状の 材料が燃料電池の改質触媒用として研究開発されている。才 ゾン発生装置は，ナノバブルオゾン水製造装置として実用化 されている。現在のアルマイト触媒の研究開発状況を表 2 に まとめた。

\section{7. 今後期待される具体的利用}

これから特に有望と思われる技術を紹介する。

(1)燃料電池改質触媒への応用 ${ }^{7)}$

6 月末に公表された水素・燃料電池戦略協議会のロード マップによれば，エネファームの名前で知られている定置型 燃料電池の販売台数が，現在 7 万台を超え， 2020 年に 140 万台, 2030 年に 530 万台の販売が予測されている。現在の

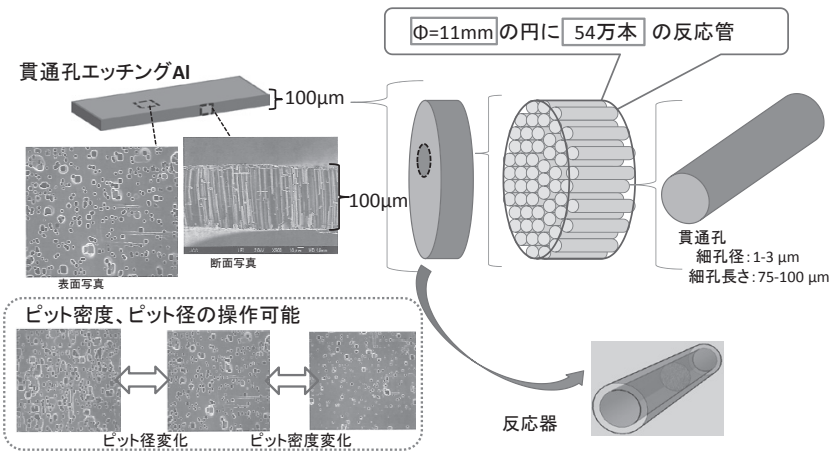

図 12 マイクロリアクター用アルマイト触媒

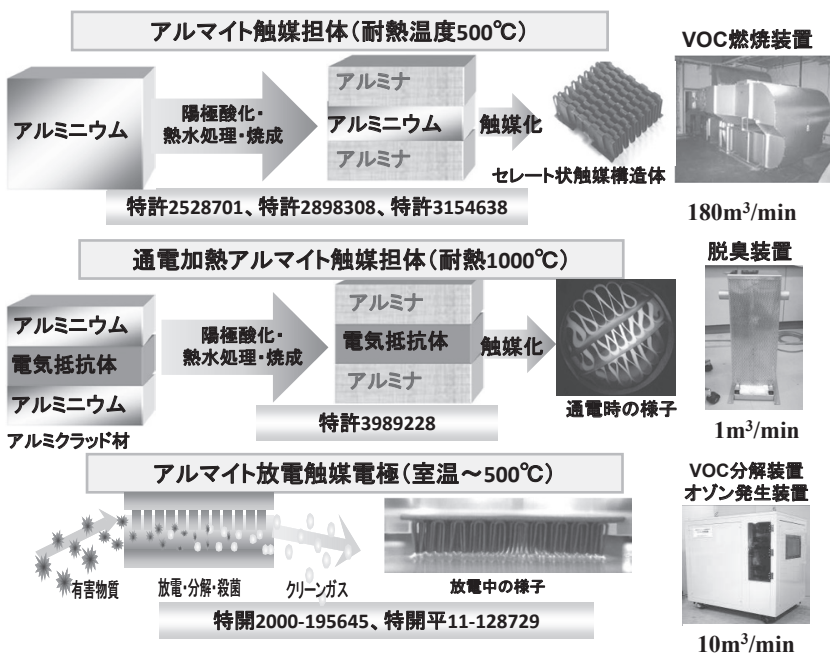

図 13 アルマイト触媒担体の利用形態と事業化事例 
表 2 アルマイト触媒の用途と研究開発状況

\begin{tabular}{|c|c|c|}
\hline 用途 & 触媒のタイプ & 開発状況 \\
\hline \multirow{3}{*}{ VOC 分解装置 } & セレート形状 & $1 \sim 200 \mathrm{~m}^{3} / \mathrm{min}$ 規模の販売実績 \\
\hline & 放電電極 & $1 \mathrm{~m} / 3 \mathrm{~min}$ 規模の実証試験 \\
\hline & 通電加熱 & $1 \sim 10 \mathrm{~m}^{3} / \mathrm{min}$ 規模の販売可能 \\
\hline 脱臭装置 & 通電加熱 & $1 \mathrm{~m}^{3} / \mathrm{min}$ の販売実績 \\
\hline \multirow{3}{*}{ 燃料電池改質装置 } & $\begin{array}{l}\text { メタン(都市ガス) 用通電加熱 } \\
\text { 灯油用通電加熱 }\end{array}$ & 両燃料に使用できるニッケル系通電加熱アルマイト触媒を開発。耐久性試験実施中 \\
\hline & $30 \mathrm{wt} \%$ エタノール水溶液用通電加熱 & $400 \mathrm{~W}$ 規模で燃料電池と繋いで LED 点灯成功 \\
\hline & メタノールマイクロ細管 & マイクロリアクター用に基礎研究段階 \\
\hline \multirow{2}{*}{ 自動車は排ガス浄化装置 } & $\begin{array}{l}\text { カソリン車用通電加熱 } \\
\end{array}$ & 微量貴金属担持炭化鉄触媒を開発。実用化耐久性試験中 \\
\hline & ディーゼル車用通電加熱 & Ti 添加 Ag アルマイト触媒を開発。実証段階 \\
\hline オゾン発生装置 & 放電電極 & 空気原料でナノバブルオゾン水製造装置として事業化段階 \\
\hline アンモニア合成 & 放電電極と通電加熱 & プラズマ反応器とアルマイト触媒反応器で基礎研究中 \\
\hline
\end{tabular}

燃料電池改質器の欠点一つは起動時間が 1 時間近くかかるこ とである。また, 商用電源との連動で起動が行われるため, 停電時に燃料電池が起動できない点である。これから予想さ れる地震災害などの非常時における電力供給の必要性を考え ると, 自立運転型の燃料電池システムが求められ, 各社研究 開発を行っている。通電型耐熱アルマイト触媒を活用すれば, 5 分以内のスタートが可能であり, そのための電力は小型の バッテリーで補うことができるので，バッテリーコストも低 減できる。2017 年頃から業務用・産業用に固体電解質型燃 料電池 (SODF) が普及し始めるが，その改質器にも通電型耐 熱アルマイト触媒が適している。また, 再生可能エネルギー 利用も今後普及して行く中で，バイオマスの改質反応器にお いても通電型耐熱アルマイト触媒が適している。セルロース 系原料から得られる $30 \mathrm{wt} \%$ 濃度のエ夕ノール水溶液を原料 にした燃料電池用水素製造装置も試験装置が稼働している段 階にある。地域における分散型燃料電池としてバイオエ夕 ノール燃料電池の可能性は高まると予想される。現在，メ夕 ン, 灯油, エタノールのいずれにも使用可能な通電型耐熱ア ルマイト触媒が開発途中にあるので，これが成功すれば，改 質器の量産化が進むため, 装置コストの低減につながるので, 大きな市場を獲得できる可能性がある。富士経済の予測では, 2025 年の燃料電池市場は 1 兆 1 千億以上と言われている。

図 14 はメ夕ンの水蒸気改質用に開発した通電型耐熱性ア ルマイト触媒の製造手順である。

この触媒を，図 15 の上に示すモードでDSS 運転を行った 結果をその下に示す。安定した改質反応結果が得られている。 現在はこの触媒を, 通電できる構造体触媒反応器の設計段階 に来ている。

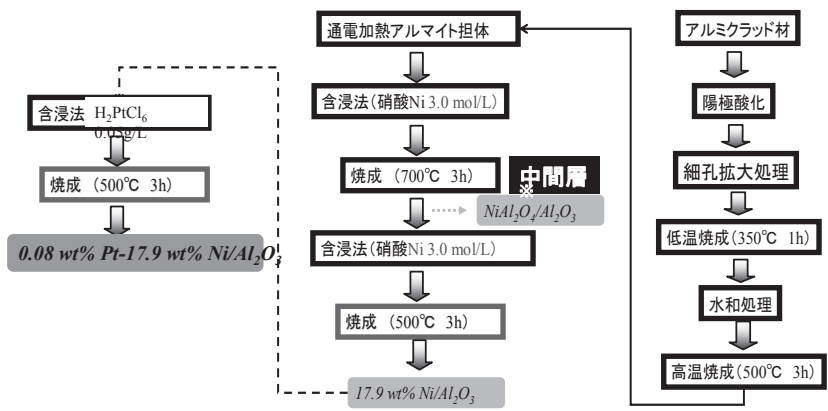

図 14 メタンの水蒸気改質用通電型耐熱性アルマイト触媒の製 造手順

\section{(2)自動車排ガス浄化用触媒 ${ }^{8)}$}

ガソリン自動車の普及台数は今後も発展途上国で急増する と予想されている。2013 年度の日本での触媒の出荷額は約 3022 億円でそのうち自動車排ガス浄化用触媒が 1814 億円と 半部以上占めている。現在の触媒は, 貴金属をべースにした 触媒であるが，今後は，資源量の制約から貴金属代替触媒が 使用されると言われており，各社研究が行われている。エン ジンの然費向上により排ガス温度が低下している。700 ํ以 下で使用できる炭化鉄触媒が通電型耐熱性アルマイト触媒と して実用化されれば，スタート時から浄化機能を発揮できる 安価な触媒として, 自動車用排ガス浄化触媒として大きな市 場を獲得できる。
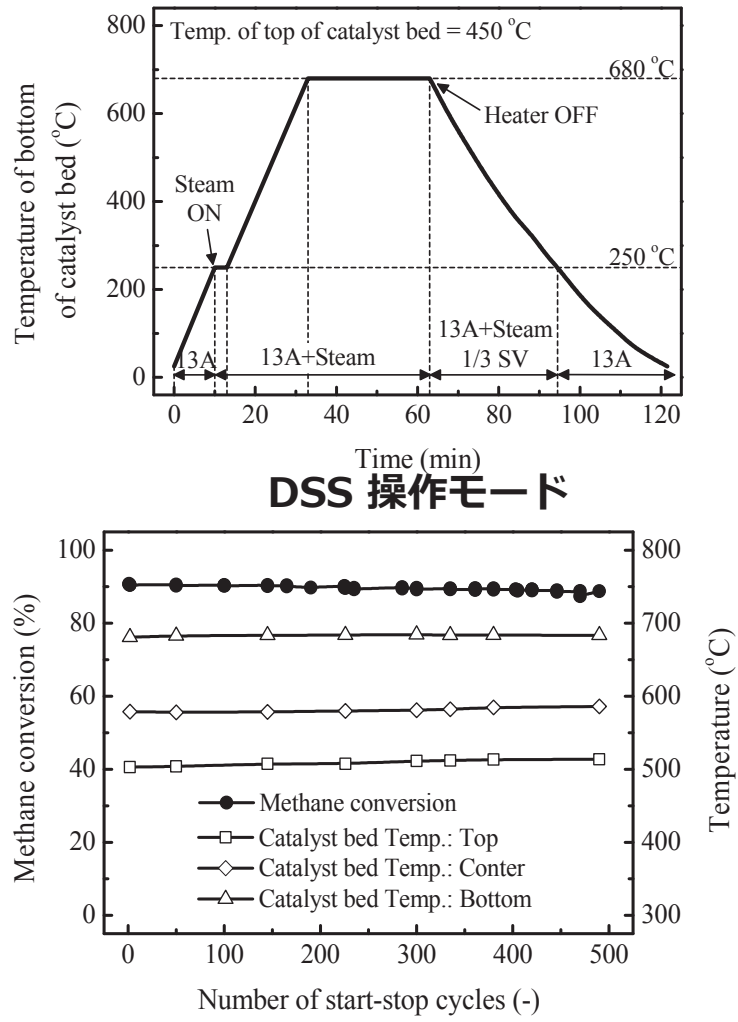

500回DSSテスト

図 15 メタンの水蒸気改質用通電型耐熱性アルマイト触媒 の運転・停止 (DSS)の 500 回繰り返し試験結果 (F/w $[\mathrm{mL} /(\mathrm{h} \cdot \mathrm{g})]=157000)$ 
表 $390 \%$ の排ガス浄化ができる触媒の温度比較

\begin{tabular}{l|c|c|c}
\hline \multirow{2}{*}{ Catalyst } & \multicolumn{3}{|c}{$\mathrm{T} 90\left[{ }^{\circ} \mathrm{C}\right]$} \\
\cline { 2 - 4 } & $\mathrm{NO}_{\mathrm{x}}$ & $\mathrm{CO}$ & $\mathrm{HC}$ \\
\hline $\begin{array}{l}\text { Our best Fe-Ce-C Alumite plate catalyst } \\
\left(\text { Co Processing } 525{ }^{\circ} \mathrm{C} 6 \mathrm{~h}\right)\end{array}$ & 496 & 451 & 385 \\
\hline $\begin{array}{l}\text { Basic three-way catalyst } \\
(\mathrm{Pt} 1[\mathrm{wt} \%])\end{array}$ & 489 & 426 & 464 \\
\hline
\end{tabular}

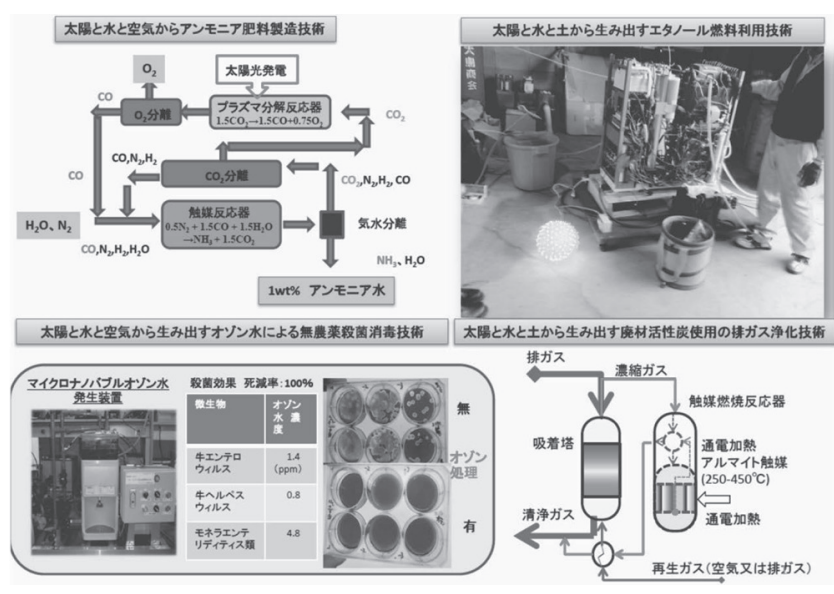

図 16 太陽と水と空気と土からのイノベーションを支えるアルマイ 卜技術の応用例

表 3 に自動車排ガスと同様の組成の模擬ガスを使用して 行った実験での貴金属触媒と鉄・炭素・セリウム系の炭化鉄 通電加熱アルマイト触媒の性能比較を示す。

この結果から, 貴金属触媒に近い温度での浄化性能が見出 されている。

(3)再生可能エネルギー利用を有効にするためのアルマイト 処理技術

再生可能エネルギーは一度電力に変換され，輸送・貯蔵・ 他の化学物質に変化される。その際にアルマイトの利用市場 として，プラズマ放電用アルマイト電極，アルマイト触媒担 体，アルマイト基板を用いる吸着分離材などがある。これら の要素技術を用いた応用として, 農業分野に対して図 16 に 示すような 4 つの応用が研究されている。

アンモニアは化石燃料である天然ガスを原料にして得られ る水素と空気から深冷分離で得られる窒素とをハーバーボッ シュ法により 400 $500{ }^{\circ} \mathrm{C}, 500$ 気圧の高温高圧下で日産 2000 トン規模で製造されている。これを 2 段の熱化学サイ クルで, 水と窒素から得る研究が行われている。このサイク ルはハイブリドサイクルと言われるもので, $\mathrm{CO}_{2}$ の分解反応 にアルマイト放電電極が使用される。

非食料系のセルロース(稲わらなど農業廃棄物)を糖化して エ夕ノール発酵により得られる低濃度エ夕ノール水溶液を原 料にした燃料電池では, エ夕ノールの水蒸気改質触媒に通電 加熱アルマイト触媒が使用される。起動時間が短く, 負荷答 性に優れた触媒として非常時の独立運転にも使えるように設
計されている ${ }^{9)}$ 。

空気から常圧で高いオゾン収率でオゾンを発生させ，それ をマイクロナノバブルにして $2 \mathrm{ppm}$ の長時間保持できるオ ゾン水を製造する装置にアルマイト放電電極が用いられる。

多孔質なアルマイト相を有する電極は, 通常の 3 倍の高いオ ゾン収率 $(\mathrm{g} / \mathrm{kWh})$ を有している ${ }^{10)}$ 。

間伐材を炭化して得られる高表面積を有する活性炭を吸着 剂にして，アルマイト基板に担持して熱応答の高い吸着体と して数百 ppm の VOC を数千 ppm まで吸着濃縮して, 通電 加熱アルマイト触媒で燃焼し, 燃焼排ガスで脱着させる投入 エネルギーゼロの VOC 分解処理装置には随所にアルマイト が使用される ${ }^{11)}$

\section{5.おわりに}

アルマイト触媒研究は 30 年以上の長きにわたり各方面で 行われてきた。触媒製造として量産化されたものもあれば, さらに付加価值を高めるために基礎研究が行われている部分 もある。世の中は, 再生可能エネルギーの導入と省エネルギー と環境を重視した設計が求められてきている。

新しい価值観のニーズに応えるために, 触媒も従来の性能 から新しい機能を持つ触媒へと変わる転換点にきている。そ のような状況の中で, アルマイト触媒は本稿で述べたように 従来の触媒にない多くの機能を内蔵ししており, 新しい市場 の対応できる潜在価值を有していると言える。

(Received August 14, 2014)

\section{文献}

1 ) 亀山秀雄 ; 化学工学, 69, 244 (2005).

2 ) 亀山秀雄; 日本エネルギー学会誌, 91, 868 (2012).

3 ) L. Wang, Q. Zhang, M. Sakurai, H. Kameyama ; J. Chem. Eng. Japan, 41, $272(2008)$

4 ) T. P. Tran, Y. Guo, L. Zhou, H. Kameyama ; J. Chem. Eng. Japan, 40, 1229 (2007).

5 ) M. S. Foo, H. Kameyama ; Proceeding of $1^{\text {st }}$ International Conference on Process Engineering and Advanced Materials 2010 (ICPEAM) June 17, PEA07 (2010).

6 ) T. P. Tran, L. Wang, D. V. Vo, H. Kameyama, T. Ueda, C. Wada, C. Uchiyama ; J. Chem. Eng. Japan, 41, 1037 (2008).

7 ) C. Okuno, L. Zhou, Y. Guo, L. Jia, M. Sakurai, H. Kameyama ; J. Chem. Eng. Japan, 47, 536 (2014).

8 ) 小田晴信, 木田智久, 郭 工, 龟山秀雄, 宮田清藏; 化学工学論文 集, 39, 250 (2013).

9 ) H. T. K. Nguyen, Y. Guo, H. Kawachi, M. Sakurai, H. Kameyama ; J. Chem. Eng. Japan, 44, 809 (2011).

10）チュアミンジン, トランタンフォン, 亀山秀雄 ; 第30回ARS弘前 コンファレンス 要旨集, p.120 (2013)

11) T. Yamaguchi, K. Aoki, M. Sakurai, H. Kameyama ; J. Chem. Eng. Japan, 46, 802 (2013). 